\title{
Selenomonas bovis sp. nov., isolated from yak rumen contents
}

\author{
Correspondence \\ Xiuzhu Dong \\ dongxz@sun.im.ac.cn
}

\author{
Kegui Zhang ${ }^{1,2}$ and Xiuzhu Dong ${ }^{1}$ \\ ${ }^{1}$ State Key Laboratory of Microbial Resources, Institute of Microbiology, Chinese Academy of \\ Sciences, Beijing 100101, PR China \\ ${ }^{2}$ Graduate University, Chinese Academy of Sciences, Beijing 100049, PR China
}

The yak (Bos grunniens) is a ruminant found mainly on the Qinghai-Tibet Plateau, China, at altitudes over $3000 \mathrm{~m}$ above sea level, with grasses as their main food. Previous work in our laboratory (An et al., 2005) based on a cultureindependent approach determined that more than $60 \%$ of the bacteria in the yak rumen clustered in not-yet-cultured groups, displaying $<90 \% 16 \mathrm{~S}$ rRNA gene sequence similarity with cultured species. In addition, a relatively large proportion of the species detected in the yak rumen grouped with fibrolytic bacteria isolated previously from rumen contents, suggesting that the yak rumen could harbour novel types of fibrolytic bacteria. Therefore, by using filter paper as the sole carbon source, we obtained a cellulose-degrading mixed-culture enrichment with yak rumen content as inoculant; a few fibrolytic and nonfibrolytic bacterial strains were isolated from the mixed culture. In this study, we describe two non-fibrolytic bacteria strains that represent a novel species of the genus Selenomonas.

Yak rumen content was inoculated into a modified basal medium (Hungate, 1966) with filter paper as the sole carbon source and grown under a gas phase of $\mathrm{N}_{2} / \mathrm{CO}_{2}$

The GenBank/EMBL/DDBJ accession numbers for the 16S rRNA gene sequences of strains $W^{\top}$ and $\mathrm{Ycb08}$ are respectively EF139191 and EU821596.

A transmission electron micrograph of a cell of strain $W^{\top}$ is available as supplementary material with the online version of this paper.
$(80: 20)$. The medium contained $20 \%$ rumen fluid and $80 \%$ basal medium. A fibrolytic mixed culture was obtained by subculturing the enrichment in the same medium for eight to ten transfers. After serial dilution in peptone-yeast extract-glucose (PYG) broth (Holdeman et al., 1977) and the use of the Hungate roll-tube technique (Hungate, 1969), single colonies were observed after incubation at $39{ }^{\circ} \mathrm{C}$ for 2 days. Colonies were picked and transferred to the same medium. The roll-tube procedure was repeated several times before strains $\mathrm{WG}^{\mathrm{T}}$ and $\mathrm{Ycb} 08$ were obtained. The purity of the isolates was examined by light microscopy. All inoculations and transfers were done with syringes and needles, and the cultures were incubated at $39{ }^{\circ} \mathrm{C}$ unless indicated. Selenomonas ruminantium subsp. ruminantium DSM $2150^{\mathrm{T}}$, S. ruminantium subsp. lactilytica DSM $2872^{\mathrm{T}}$, Selenomonas sputigena DSM $20758^{\mathrm{T}}$ and Mitsuokella jalaludinii DSM $13811^{\mathrm{T}}$ were purchased from the Deutsche Sammlung von Mikroorganismen und Zellkulturen (Braunschweig, Germany) and served as reference strains in physiological characterization tests.

Cell morphology was examined under a light microscope (Olympus BH-2) and an electron microscope (Hitachi H$600 \mathrm{~A}$ ). For electron microscopy studies, bacterial cells were negatively stained with uranyl acetate. Spore formation was examined by phase-contrast microscopy at the end of growth as well as by heat treatment in a water bath at $80{ }^{\circ} \mathrm{C}$ for $10 \mathrm{~min}$. 
Cells were Gram-negative, typical curved rods, $0.9-1.1 \times 4$ $6 \mu \mathrm{m}$, and occurred singly or in pairs. Spores were never observed, and the strains could not survive heat treatment at $80{ }^{\circ} \mathrm{C}$ for $10 \mathrm{~min}$. Negatively stained cells revealed the presence of four to six flagella in a tuft situated near the centre of the concave side (Supplementary Fig. S1, available in IJSEM Online).

Growth was determined by monitoring the $\mathrm{OD}_{600}$ of the culture in PYG medium at $39{ }^{\circ} \mathrm{C}$. The strains were strictly anaerobic; no growth occurred when exposed to air. The generation time of strain $\mathrm{WG}^{\mathrm{T}}$ was determined as $2.3 \mathrm{~h}$ by monitoring the $\mathrm{OD}_{600}$ at 30 min intervals for $24 \mathrm{~h}$. The temperature profile of strain $\mathrm{WG}^{\mathrm{T}}$ was determined in a water bath from 20 to $50{ }^{\circ} \mathrm{C}$ at $1{ }^{\circ} \mathrm{C}$ intervals (pH 7.0) and growth was observed between 27 and $46{ }^{\circ} \mathrm{C}$, with optimal growth at $39{ }^{\circ} \mathrm{C}$. The $\mathrm{pH}$ range for growth was $\mathrm{pH} 4.2-8.3$, with optimal growth at around $\mathrm{pH}$ 7.0-7.2, as determined in PYG broth at various $\mathrm{pH}$ values adjusted with $\mathrm{Na}_{2} \mathrm{HPO}_{4}$ and $\mathrm{NaH}_{2} \mathrm{PO}_{4}$.

The end products from glucose fermentation were determined by growing strains $\mathrm{WG}^{\mathrm{T}}$ and $\mathrm{Ycb} 08$ in PYG medium; short-chain fatty acids were then analysed by using a gas chromatograph (GC-14B; Shimadzu) equipped with a flame-ionization detector (column temperature $230{ }^{\circ} \mathrm{C}$, injector $250{ }^{\circ} \mathrm{C}$, detector $280{ }^{\circ} \mathrm{C}$ ). The carrier gas was $\mathrm{N}_{2}$ at a flow rate of $30 \mathrm{ml} \mathrm{min}{ }^{-1}$. It was determined that strain $\mathrm{WG}^{\mathrm{T}}$ and $\mathrm{Ycb} 08$ produced acetate, propionate and $\mathrm{CO}_{2}$ from glucose at a molar ratio of $0.7: 1.1: 1.2$.

Substrate utilization was tested by growing the two strains in PY medium (Holdeman et al., 1977) separately containing each of the following substrates: lactate, glycerol, dulcitol, mannitol, sorbitol, xylose, arabinose, glucose, mannose, cellobiose, lactose, sucrose, trehalose, melibiose, raffinose, inulin, salicin and aesculin. Stock solutions of the test compounds were prepared anaerobically, sterilized by filtration and injected into PY medium to the final concentration of $1 \%(\mathrm{w} / \mathrm{v})$. Other physiological characteristics including the Voges-Proskauer test, nitrate reduction, indole production, $\mathrm{H}_{2} \mathrm{~S}$ production, methyl red test and gelatin liquefaction were determined according to Holdeman et al. (1977).

The two strains exhibited almost identical physiological and biochemical profiles except that strain Ycb08 could not ferment inulin or raffinose. Other physiological characteristics are listed in the species description.

Genomic DNA was extracted and purified according to Marmur (1961). The G+C content of the DNA was determined by the thermal denaturation method (Marmur \& Doty, 1962) using a DU800 spectrophotometer (Beckman) with Escherichia coli K-12 DNA as the reference. The G+C contents of the genomic DNA for strains $\mathrm{WG}^{\mathrm{T}}$ and $\mathrm{Ycb} 08$ were determined as $63.9 \pm 0.2$ and $62.5 \pm 0.2 \mathrm{~mol} \%$, respectively, from three parallel measurements.

The 16S rRNA gene was amplified using the bacterial universal primers 27F and 1541R (Weisburg et al., 1991).
Purified PCR products approximately $1.5 \mathrm{kbp}$ in length were cloned to Escherichia coli DH5 $\alpha$ and sequenced by the Sangon Biological Engineering Technology Service (Shanghai, China). The sequences were submitted to GenBank to search for similar sequences using BLAST algorithm. The $16 \mathrm{~S}$ rRNA gene sequences of strain $\mathrm{WG}^{\mathrm{T}}$ and reference strains retrieved from GenBank were aligned using the CLUSTAL_X program v. 1.83 (Thompson et al., 1997). Phylogenetic trees were constructed using the neighbour-joining, UPGMA, minimum evolution and maximum-parsimony methods as implemented in MEGA3 (Kumar et al., 2004). Stability of groupings was evaluated by bootstrap analysis of 1000 datasets (Felsenstein, 1985). Strains $\mathrm{WG}^{\mathrm{T}}$ and Ycb08 displayed $16 \mathrm{~S}$ rRNA gene sequence similarity of $99.7 \%$; they were therefore considered to represent a single species. To ascertain the phylogenetic position of the new isolates, the complete $16 \mathrm{~S}$ rRNA gene sequences were compared with the most similar sequences retrieved from GenBank. On the basis of a consensus $1379 \mathrm{bp} 16 \mathrm{~S}$ rRNA gene sequence, a phylogenetic tree rooted with Bacillus subtilis DSM $10^{\mathrm{T}}$ was constructed (Fig. 1). It was shown that the two strains clustered with the members of the genera Selenomonas and Mitsuokella and were closest to M. jalaludinii $\mathrm{M} 9^{\mathrm{T}}$ ( $95.5 \% 16 \mathrm{~S}$ rRNA gene sequence similarity), followed by S. ruminantium subsp. ruminantium $\mathrm{GA} 192^{\mathrm{T}}(95.4 \%), S$. ruminantium subsp. lactilytica $\mathrm{HD}_{4}(95.2 \%)$ and Mitsuokella multacida NCTC $10934^{\mathrm{T}}$ (95.1\%). According to the well-accepted bacterial species delimitation of less than $97 \% 16 \mathrm{~S}$ rRNA gene sequence similarity (Wayne et al., 1987), strains $\mathrm{WG}^{\mathrm{T}}$ and Ycb08 could represent a novel species affiliated either to the genus Selenomonas or Mitsuokella.

Based on the genus descriptions, members of Mitsuokella are characterized by a cell morphology of stout rods without flagella (Mitsuoka et al., 1974; Holdeman et al., 1984; Lan et al., 2002), while cells of the genus Selenomonas are curved to helical rods, motile with a typical flagellar arrangement as a tuft near the centre of the concave side (Bryant, 1984; Kingsley \& Hoeniger, 1973). Strain $\mathrm{WG}^{\mathrm{T}}$ presented crescent-shaped cells with flagella on the concave side; together with other differential characteristics listed in Table 1, the two strains can be classified in the genus Selenomonas. Furthermore, the two strains resembled other members of the genus Selenomonas in metabolic features, such as the use of a variety of carbohydrates as substrates and the production of acetate, propionate and $\mathrm{CO}_{2}$ from glucose, as well as production of $\mathrm{H}_{2} \mathrm{~S}$ from L-cysteine but the absence of nitrate reduction (Table 1). However, strains $\mathrm{WG}^{\mathrm{T}}$ and $\mathrm{Ycb} 08$ displayed $<97 \% 16 \mathrm{~S}$ rRNA gene sequence similarity with described Selenomonas species and differed from their closest relative, S. ruminantium subsp. ruminantium DSM $2150^{\mathrm{T}}$, in their higher $\mathrm{G}+\mathrm{C}$ content and by liquefying gelatin but not fermenting dulcitol, mannitol, sorbitol and xylose. Thus, on the basis of DNA G $+\mathrm{C}$ content and the physiological and phylogenetic traits described above, strains $\mathrm{WG}^{\mathrm{T}}$ and $\mathrm{Ycb} 08$ represent a novel 


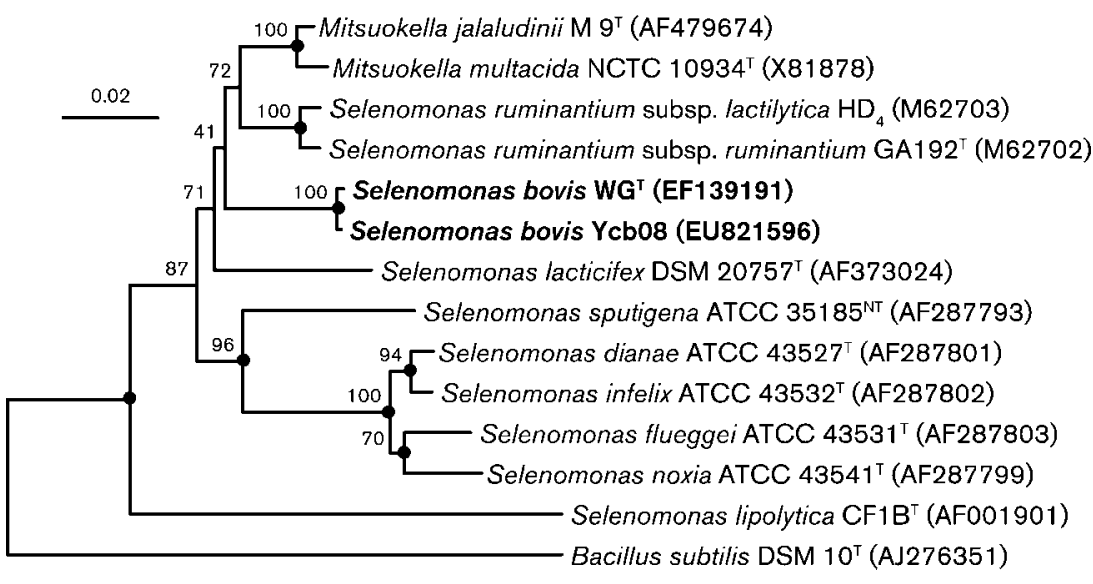

Fig. 1. Phylogenetic tree of Selenomonas species and related organisms based on a $1379 \mathrm{bp}$ fragment of the $16 \mathrm{~S}$ rRNA gene, showing the position of strains $\mathrm{WG}^{\top}$ and Ycb08. The tree was rooted with Bacillus subtilis DSM $10^{\top}$ and constructed using the neighbour-joining method. Solid circles indicate that the corresponding nodes (groups) were also recovered by the maximum-parsimony and minimum-evolution methods. Numbers at nodes represent percentages of bootstrap support based on 1000 resampled datasets of the neighbour-joining method. GenBank accession numbers are given in parentheses. Bar, $2 \%$ sequence divergence.

species of the genus Selenomonas, for which the name Selenomonas bovis sp. nov. is proposed.

\section{Description of Selenomonas bovis sp. nov.}

Selenomonas bovis (bo'vis. L. gen. n. bovis of a cow, of a bovine, referring to the isolation of the first strains from yak rumen contents).

Gram-negative, crescent-shaped rods, 4-6 $\mu \mathrm{m}$ long and $0.9-1.1 \mu \mathrm{m}$ wide. No spore formation is observed. Flagella (four to six) are arranged linearly as a tuft near the centre of the concave side of the cell. The temperature range for growth is $27-46{ }^{\circ} \mathrm{C}$; optimum growth at $39{ }^{\circ} \mathrm{C}$. Grows at $\mathrm{pH}$ 4.2-8.3, with optimum growth at $\mathrm{pH} 7.0-7.2$. The generation time is $2.3 \mathrm{~h}$ when grown on glucose at $39{ }^{\circ} \mathrm{C}$. The final $\mathrm{pH}$ in PYG medium is 4.5. Utilizes arabinose, glucose, mannose, cellobiose, lactose, sucrose, trehalose, melibiose, raffinose, salicin and aesculin but not lactate, xylose, starch, dulcitol, mannitol or sorbitol. The end products of glucose fermentation are acetate, propionate and $\mathrm{CO}_{2}$ according to the equation 1 glucose $\rightarrow 0.7$ acetate +1.1 propionate $+1.2 \mathrm{CO}_{2}$. Liquefies gelatin and

Table 1. Differential characteristics of strains $W G^{\top}$ and $Y c b 08$ and phylogenetically related type strains

Strains: 1, strain $\mathrm{WG}^{\mathrm{T}} ; 2$, strain Ycb08; 3, S. ruminantium subsp. ruminantium DSM $2150^{\mathrm{T}}$ (data from Bryant, 1956, 1984); 4, S. ruminantium subsp. lactilytica DSM $2872^{\mathrm{T}}$ (unless indicated, data from Bryant, 1956, 1984); 5, S. sputigena DSM $20758^{\mathrm{T}}$ (unless indicated, data from Bryant, 1956, 1984), 6, M. jalaludinii DSM $13811^{\mathrm{T}}$ (Lan et al., 2002); 7, M. multacida NCTC 10934 ${ }^{\mathrm{T}}$ (Mitsuoka et al., 1974; Holdeman et al., 1984).

\begin{tabular}{|c|c|c|c|c|c|c|c|}
\hline Characteristic & 1 & 2 & 3 & 4 & 5 & 6 & 7 \\
\hline Isolation source & Yak & Yak & Cattle & Cattle & Human & Cattle & Human \\
\hline Morphology* & $\mathrm{CR}$ & $\mathrm{CR}$ & $\mathrm{CR}$ & $\mathrm{CR}$ & $\mathrm{CR}$ & SR & SR \\
\hline Flagellar arrangement $\dagger$ & LA & LA & LA & LA & LA & $\mathrm{NF}$ & $\mathrm{NF}$ \\
\hline Voges-Proskauer test & - & - & - & - & - & + & + \\
\hline Nitrate reduction & - & - & - & - & + & + & + \\
\hline $\mathrm{H}_{2} \mathrm{~S}$ production & + & + & + & + & - & - & - \\
\hline Gelatin liquefaction & + & + & - & - & - & - & - \\
\hline \multicolumn{8}{|l|}{ Acid production from: } \\
\hline Glycerol & - & - & - & + & + & + & - \\
\hline Dulcitol & - & - & + & + & - & - & - \\
\hline Mannitol & - & - & + & + & + & - & + \\
\hline Sorbitol & - & - & + & + & - & + & - \\
\hline Xylose & - & - & + & + & - & + & + \\
\hline Mannose & + & + & + & $+\ddagger$ & - & + & + \\
\hline Raffinose & + & - & + & + & $+末$ & - & + \\
\hline Inulin & + & - & + & + & + & - & - \\
\hline DNA G + C content $(\mathrm{mol} \%)$ & $63.9 \pm 0.2$ & $62.5 \pm 0.2$ & $54.2 \pm 0.2$ & $55.2 \pm 0.4$ & 61 & 56.8 & 57.3 \\
\hline
\end{tabular}

${ }^{*} \mathrm{CR}$, Curved rods; SR, stout rods.

$\dagger \mathrm{LA}$, Linearly arranged as a tuft near the centre of the concave side; NF, no flagella.

$\ddagger$ Data from this study. 
produces $\mathrm{H}_{2} \mathrm{~S}$ but not indole. Does not reduce nitrate. Voges-Proskauer and methyl red tests are negative. The $\mathrm{G}+\mathrm{C}$ content of the genomic DNA of the type strain is $63.9 \pm 0.2 \mathrm{~mol} \%$.

The type strain, $\mathrm{WG}^{\mathrm{T}}\left(=\mathrm{CGMCC} 1.5073^{\mathrm{T}}=\mathrm{JCM} 15470^{\mathrm{T}}\right)$, and a second strain, Ycb08, were isolated from yak rumen contents.

\section{Acknowledgements}

This study was supported by the National Basic Research Program of China (2004CB719602) and the China National Science Foundation (30470041).

\section{References}

An, D., Dong, X. \& Dong, Z. (2005). Prokaryote diversity in the rumen of yak (Bos grunniens) and Jinnan cattle (Bos taurus) estimated by $16 \mathrm{~S}$ rDNA homology analyses. Anaerobe 11, 207-215.

Bryant, M. P. (1956). The characteristics of strains of Selenomonas isolated from bovine rumen contents. J Bacteriol 72, 162-167.

Bryant, M. P. (1984). Genus IX. Selenomonas Von Prowazek 1913, $36^{\mathrm{AL}}$. In Bergey's Manual of Systematic Bacteriology, vol. 1, pp. 650653. Edited by N. R. Krieg \& J. G. Holt. Baltimore: Williams \& Wilkins.

Felsenstein, J. (1985). Confidence limits on phylogenies: an approach using the bootstrap. Evolution 39, 783-791.

Holdeman, L. V., Cato, E. P. \& Moore, M. E. C. (1977). Anaerobe Laboratory Manual, 4th edn. Blacksburg, VA: Virginia Polytechnic Institute \& State University.

Holdeman, L. V., Kelley, R. W. \& Moore, W. E. C. (1984). Genus I. Bacteroides Castellani and Chalmers 1919, 959 ${ }^{\mathrm{AL}}$. In Bergey's Manual of Systematic Bacteriology, vol. 1, pp. 604-631. Edited by N. R. Krieg \& J. G. Holt. Baltimore: Williams \& Wilkins.

Hungate, R. E. (1966). The Rumen and its Microbes. New York: Academic Press.

Hungate, R. E. (1969). A roll-tube method for cultivation of strict anaerobes. Methods Microbiol 3B, 117-132.

Kingsley, V. V. \& Hoeniger, J. F. (1973). Growth, structure and classification of Selenomonas. Bacteriol Rev 37, 479-521.

Kumar, S., Tamura, K. \& Nei, M. (2004). MEGA3: integrated software for molecular evolutionary genetics analysis and sequence alignment. Brief Bioinform 5, 150-163.

Lan, G. Q., Ho, Y. W. \& Abdullah, N. (2002). Mitsuokella jalaludinii sp. nov., from the rumens of cattle in Malaysia. Int J Syst Evol Microbiol 52, 713-718.

Marmur, J. (1961). A procedure for the isolation of deoxyribonucleic acid from microorganisms. J Mol Biol 3, 208-218.

Marmur, J. \& Doty, P. (1962). Determination of the base composition of deoxyribonucleic acid from its thermal denaturation temperature. $J$ Mol Biol 5, 109-118.

Mitsuoka, T., Terada, A., Watanabe, K. \& Uchida, K. (1974). Bacteroides multiacidus, a new species from the feces of humans and pigs. Int J Syst Bacteriol 24, 35-41.

Thompson, J. D., Gibson, T. J., Plewniak, F., Jeanmougin, F. \& Higgins, D. G. (1997). The CLUSTAL_X windows interface: flexible strategies for multiple sequence alignment aided by quality analysis tools. Nucleic Acids Res 25, 4876-4882.

Wayne, L. G., Brenner, D. J., Colwell, R. R., Grimont, P. A. D., Kandler, O., Krichevsky, M. I., Moore, L. H., Moore, W. E. C., Murray, R. G. E. \& other authors (1987). International Committee on Systematic Bacteriology. Report of the ad hoc committee on reconciliation of approaches to bacterial systematics. Int J Syst Bacteriol 37, 463-464.

Weisburg, W. G., Barns, S. M., Pelletier, D. A. \& Lane, D. J. (1991). 16 S ribosomal DNA amplification for phylogenetic study. J Bacteriol 173, 697-703. 